\title{
APPLICATION OF CRUDE PECTINASES PRODUCED BY ASPERGILLUS SOJAE (ATCC 20235) AS A PROCESSING AID FOR BANANA JUICE EXTRACTION
}

\author{
Gehad M. El-Shenawi and M. B. Atta \\ Food Science and Technology Department, Faculty of Agriculture, Tanta University, Egypt
}

Received: May 7, 2016

Accepted: Jul. 3, 2016

\begin{abstract}
Crude pectinases produced by genetically modified Aspergillus sojae (ATCC 20235) namely PGzyme was used for extraction and clarification of banana juice comparing with two commercially available pectinase (Fructozym and Flavourozyme). Therefore, endopolygalacturonase (Endo-PG), exopolygalactouronase (Exo-PG) and polymethylegalacturonase (PMG) activities in each enzyme preparation were estimated. The results revealed that Fructozym is more effective to extract and clarify of banana juice rather than of PGzyme. While, Flavourzyme has no marked effect on the extraction or clarification of the banana juice. Physicochemical characteristics of the produced juices by the studied different enzymes were also discussed.
\end{abstract}

Key words: Pectinases, banana juice, physicochemical characteristics

\section{INTRODUCTION}

Fungal pectinases are widely utilized in the industrial sector where they represent more than $25 \%$ of the total commercial enzymes which are used in food processing (Moussa-Ayoub et al., 2011; Sagu et al., 2014). Fungal pectinases are produced at the commercial scale (Naidu and Panda, 1998) and broadly used in the field of food processing (Grassin and Fauquembergue, 1996; Kashyap et al., 2001). Pectinases have many applications in extraction of juice from soft fruits, clarification of fruit juices and wine, maceration of plant tissue, liquefaction and oil extraction (Mutlu et al., 1999; Kashyap et al., 2001; Jayani et al., 2005). They are preferred rather than other chemical methods due to high affinity of enzymes to their substrates and generate less toxicity (Hoondal et al., 2002). Crude pectinase (PGzyme) is mainly a group of pectinolytic enzymes that are produced by the fermentation process of Aspergillus sojae growing on agro wastes (Naidu and Panda, 1998; Pandey et al., 2000). The product of this fermentation has obtained as GRAS (Generally Recognized As Safe) status, which has approved its use in the food industry (Heerd et al., 2012). Endopolygalacturonases (Endo-PG) [EC3.2.1.15], Exopolygalacturonase (ExoPG) [EC 3.2.1.67] and polymethylgalacturonase (Exo- PMG) [EC 3.2.1.82] are hydrolyzed the glycosidic bonds while pectin lyase (EC 4.2.2.10) belongs to trans elimination cleavage enzyme. Pectinmethylestrase (PME) [EC 3.1. 1. 11] is a degrading enzyme which deesterifies methyl ester linkage in pectic substances (Jayani, et al., 2005). Recently increases attention has been focused on the utilization of polycarbohydrates hydrolysis enzymes in order to overcome the loss of juice yield and improve the juice quality (Kulkarni et al., 2010; Vijayanand et al., 2010; Vishal et al., 2015). Banana (Musa $s p p$.) is one of the most consumed fruit around the world as fresh. The fruits are rich in carbohydrates and minerals especially potassium and magnesium (Kyamuhangire et al., 2002). Over-ripe fruits that are normally rejected by the consumers and unmarketable (Emerald and Sreenarayanan, 1999) could be processed as banana juice 
under good manufacturing practices (Mohapatra et al., 2011). The juice has special flavor that can use in various foods and drinks (Shahadan and Abdullah, 1995). The presence of large amounts of polysaccharide in banana cells has critical effect on the juice yield extraction (Lee et al., 2006).

This work was carried out to report the use of crude enzyme preparation namely PGzyme produced by solid state fermentation from genetically modified Aspergillus sojae (ATCC 20235) as a processing aid for banana juice extraction and clarification.

\section{MATERIALS AND METHODS}

Materials:

Enzymes: Two kinds of fungal commercial enzymes namely Fructozym ${ }^{\circledR} \mathrm{P}$ was obtained from (Erbaslöh Geisenheim AG- Germany) and Flavourzyme ${ }^{\circledR} 500$ MG purchased from Novozymes (Swiss land). Crude pectinases PGzyme was produced by genetic modified Aspergillus sojae (3UVATCC 20235) on solid-state fermentation systems using sugar beet pellets and wheat bran as fermentation medium. The enzyme was harvested after 6 days of fermentation by adding tap water, shaking and centrifugation according to Heerd, (2013). Banana (Musa spp.) fruits were purchased from the local market of Bremen City (Germany) at May 2015 and kept at room temperature until reach to stage 4 of ripping. All chemicals used are analytical grade.

\section{Methods \\ Protein assay}

Total protein content of enzyme $(\mathrm{mg} / \mathrm{ml})$ was calorimetrically determined according to Bradford (1976) with slight modification from Thermo Scientific using bovine serum albumin BSA $(2 \mathrm{mg} / \mathrm{ml})$ as a standard protein.

\section{Determination of pectolytic enzyme activity}

Endo-polygalacturonase (Endo-PG) activity was determined calorimetrically using Ruthenium red at $535 \mathrm{~nm}$ as described by Ortiz et al. (2014). Mean Exopolygalacturonase (Exo-PG) activity was determined using 3,5-dinitro salicylic acid (DNS) according to Miller, (1959) with slight modification by Silva et al. (2005). Exopolymethylgalacturonase (Exo-PMG) was determined via the method described by Heerd et al. (2012).

\section{Banana juice extraction and clarification}

The extraction and clarification of banana fruits by selected enzymes were performed at $40^{\circ} \mathrm{C}$ for $3 \mathrm{hrs}$ by adding (10 U enzyme preparation $/ \mathrm{mL}$ ) according to the method described by Tadakittisarn et al. (2007).

\section{Physical analysis of banana juice}

Physical characteriaztics of banana juice including clarity by measuring the juice transmitance at $670 \mathrm{~nm}$ (Johnson et al., 1995), brwoing index (BI) according to Youn et al. (2004), total soluble solids (TSS) and reflactive index (RI) using Abeè refractometer (Al-Hooti et al., 2002), $\mathrm{pH}$ value using $\mathrm{pH}$-meter $(\mathrm{HI} 2211 \mathrm{pH} / \mathrm{ORP}$ meter HANNA) at $25^{\circ} \mathrm{C}$ according to AOAC (1995), viscosity using Ostwald viscometer at $25^{\circ} \mathrm{C}$ and turbidity as Nephelometer Turbidity Unit (NTU) using nephelometer (a Hack turbid meter, Germany) following the method of Byaruagaba-Bazarike et al. (2012) were performed.

\section{Determination of reducing sugar in banana juice}

Reducing sugars (RS) using 3,5dinitrosalicylic acid (DNS) was determined as described by Negrulescu et al. (2012) with some modification. A microplate reader (Tecan Deutschland $\mathrm{GmbH}$ ) was performed in triplicates. Standard curve was carried out parallel under the same conditions. 


\section{Statistical analysis}

Data are represented means and standard deviation $(\mathrm{M} \pm \mathrm{SD})$ for three replicates. Analysis of variance (ANOVA) was applied between means and were further tested using the Dunc's according to SAS (2004).

\section{RESULTS AND DISCUSSION Protein content and enzyme activity}

Results of Table (1) display that Fructozym contains the highest $(p<0.05)$ protein content $(2.08 \mathrm{mg} / \mathrm{ml})$ among the three studied enzymes. On the other hand, PGzyme had the lowest protein $(0.27 \mathrm{mg} / \mathrm{ml})$. The same trend is also shown for Endo-PG activity, since Endo-PG activity of $1.0 \%$ Flavourzyme is $107.1 \mathrm{U} / \mathrm{ml}$ which represents the medium activity among PGzyme (42.2 $\mathrm{U} / \mathrm{ml}$ ) and Fructozym (133.9 U/ml). Although, Endo-PG activity of Fructozym significantly $(p<0.05)$ higher than that of PGzyme but its Exo-PG activity $(281.0 \mathrm{U} / \mathrm{ml})$ was lower than that of PGzyme $(336.0 \mathrm{U} / \mathrm{ml})$. At the same time, no significant $(p<0.05)$ difference between PMG activities of both enzymes was detected. Nevertheless, Flavourzyme had moderate activity between PGzyme and Fructozym in Endo-PG $(107.1 \mathrm{U} / \mathrm{mL})$ while a lower activity $(50.0 \mathrm{U} / \mathrm{mL})$ was detected in Exo-PG and Exo-PMG (9.3 U/mL). These variations may be related to the fungus strain, production conditions and method of enzyme separation (Heerd, 2013). It is well known that Endo-PG catalyses random hydrolysis of $\alpha-1 \rightarrow 4$ glycosidic linkages in pectin chain as results viscosity of pectin solutions are decreased and insoluble pectin turns to soluble one. While Exo-PG catalyses hydrolysis in a sequential fashion of $\alpha-1 \rightarrow 4$ glycosidic from the non-reducing end in pectin split galacturonic acid and/or monosaccharide which leads to increase the reducing power of the pectin solutions (Kashyap et al., 2001; Jayani et al., 2005).The PMG's are group of enzymes hydrolyzed the glycosidic bonds in the esterified pectin (Jayani et al., 2005).

\section{Specific activity (SA)}

Specific activity (SA as units/mg protein) is the number of enzyme units per $\mathrm{ml}$ divided by the concentration of protein in $\mathrm{mg} / \mathrm{ml}$. It is an important measure for enzyme purity. Although calculating SA value of the enzyme depends mainly on the enzyme activity, they are usually greatly differing from each other's depending on the definition of the enzyme unit. Thus, enzyme batches that are below the expected SA value may contain impurities or inactivated enzyme molecules.

Table 1: Protein content $(\mathrm{mg} / \mathrm{ml})$ and activity $(\mathrm{U} / \mathrm{ml})$ of enzymes preparation

\begin{tabular}{|c|c|c|c|}
\hline Enzyme pattern & PGzyme & 1\% Flavourzyme & Fructozym \\
\hline Protein $(\mathbf{m g} / \mathrm{mL})$ & $0.27 \pm 0.06 \mathrm{c}$ & $0.59 \pm 0.15 \mathrm{~b}$ & $2.08 \pm 0.19 \mathrm{a}$ \\
\hline Endo-PG $(\mathbf{U} / \mathrm{mL})$ & $42.2 \pm 4.9 \mathrm{c}$ & $107.1 \pm 2.22 \mathrm{~b}$ & $133.9 \pm 0.02 \mathrm{a}$ \\
\hline Exo-PG $(\mathbf{U} / \mathrm{mL})$ & $336 \pm 0.18 \mathrm{a}$ & $51 \pm 0.09 \mathrm{c}$ & $281 \pm 0.09 \mathrm{~b}$ \\
\hline Exo-PMG $(\mathbf{U} / \mathrm{mL})$ & $21.65 \pm 2.04 \mathrm{a}$ & $9.27 \pm 0.58 \mathrm{~b}$ & $22.31 \pm 1.23 \mathrm{a}$ \\
\hline
\end{tabular}

$\mathrm{M} \pm \mathrm{SD}=$ means and standard deviation of three successful trails

In a row, means followed by the same letter are not significantly different at $5 \%$ level 
The SA is inversely proportional to the amount of the protein in enzyme preparation. Whenever, protein content increased in the enzyme solution, the SA decreased. Therefore, as the protein content in the enzyme preparations increased, SA of Endo-PG, Exo-PG and Exo-PMG decreased (Fig. $1 \mathrm{~A}, \mathrm{~B}$ and $\mathrm{C}$ ).

\section{Effect of enzymes treatment on characteristics of banana Juice}

Physicochemical properties including browning index $(\mathrm{BI})$ at $420 \mathrm{~nm}$ (expressing color), turbidity, refractive index (RI), viscosity, reducing sugar (RS) and $\mathrm{pH}$ of juice are playing an important role on the quality and acceptance of consumer.

\section{Yield and viscosity}

The yield of banana juice is significantly $(p<0.05)$ increased due to the use of the pectinolytic enzyme preparations. Where, the yield and viscosity of the juice extracted without enzyme (control) is $(48.2 \%)$ significantly $(p<0.05)$ increases to $60.5 \%$ and $72.8 \%$ when extracted with PGzyme and Fructozym, respectively. On the other hand, viscosity of the juice decreases due to the use of enzymes. The viscosity of control juice is $7.62 \mathrm{cp}$ decreases to $1.48 \mathrm{cp}$ and $1.38 \mathrm{cp}$ for juice extracted by PGzyme and Fructozym, respectively (Fig. 2). The decrement of viscosity may be related to the degradation of pectin and pectic substances in banana pulp led to reduce water holding capacity of the macromolecules and the free-water release to the system causing lower viscosity and extra yield (Kashyap et al., 2001; Lee et al., 2006).
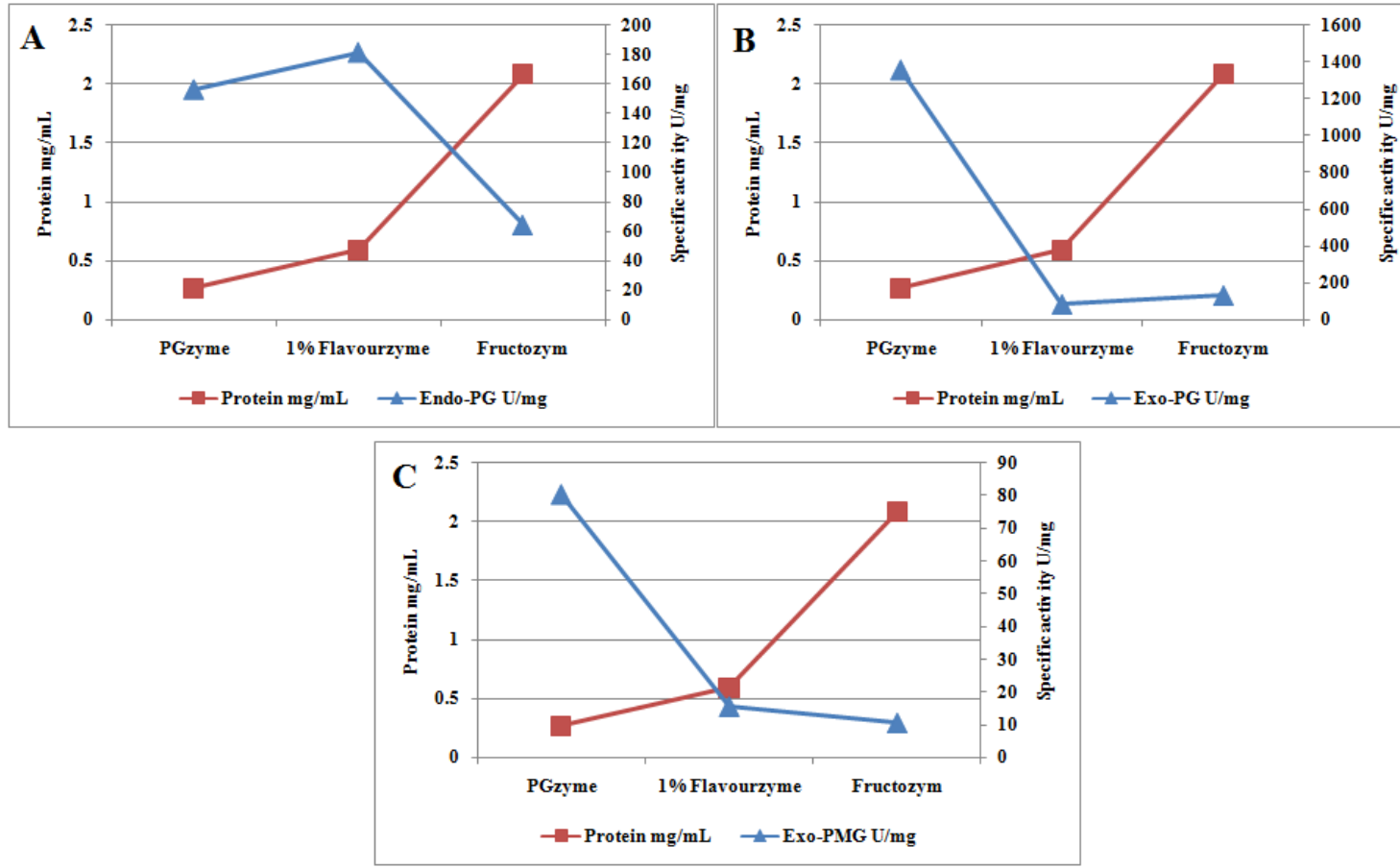

Figure (1): Specific activity (U/mg) comparing with protein content $(\mathrm{mg} / \mathrm{mL})$,
A: Endopolygalacturonase,
C: Exopolymethylgalacturonase

B: Exopolygalacturonase and 


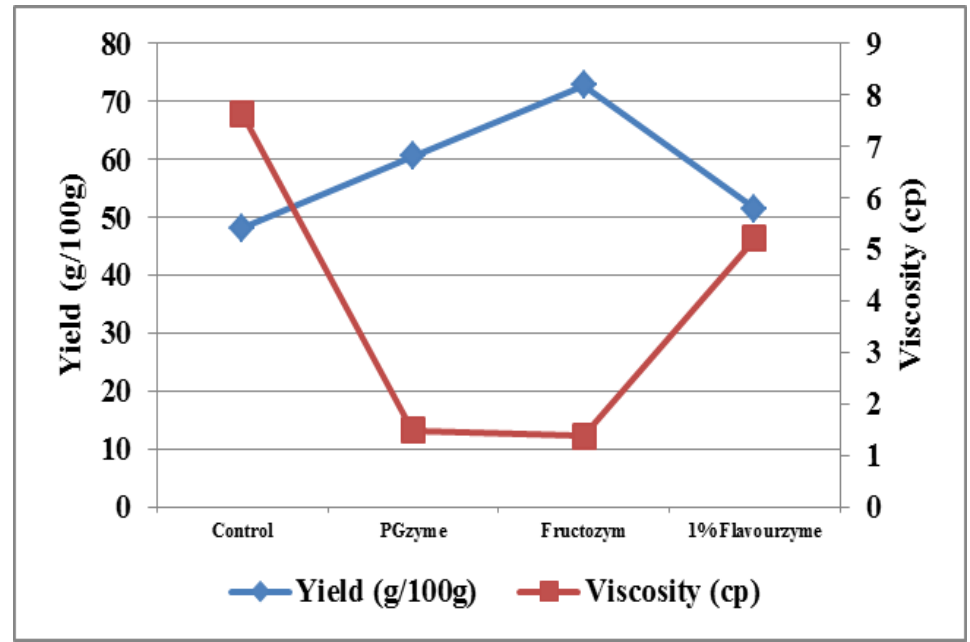

Figure (2): Effect of enzymes treatment on the yield and viscosity of banana juice

This implies that Fructozym and PGzyme are more effectively on hydrolysis of pectic substances in banana pulp than that of Flavourzyme where there are no significant $(p>0.05)$ differences between the yield and viscosity of control juice and that juice extracted by Flavourzyme. As for Fructozym and PGzyme, they have high amounts of Endo-PG and Exo-PMG, which they could degrading pectin in meddle lamella and cell walls converting the insoluble pectic substances in solid state to soluble one and free-run juice release (Kyamuhangire et al., 2002). As a result, increases the juice yield and depresses its viscosity.

\section{Clarity and Turbidity}

The clarity of juice is an important index for the degree of juice clarification (Sin et al., 2006). The clarity is dramatically increased in the juice extracted by Fructozym (98.6\%) and PGzyme (97.4\%) comparing with that of Flavourzyme (25.5\%) and control (19.5\%) (Fig 3). The presence of other enzymes may increase the rate of clarification owing to reduce electrostatic repulsion between the charged protein particles, which caused clouds, leading to aggregate the dispersed protein particles into larger particles and eventually precipitate (Sin et al., 2006).
Contrary to the increase of clarity due to the presence of enzyme, turbidity decreases. Where, the turbidity of the control is 781.3 NTU which significantly $(p<0.05)$ drops to 12.00 and $61.3 \mathrm{NTU}$ for juice extracted by Fructozym and PGzyme, respectively. The turbidity of juice extracted by Fructozym is the best one. This may be attributed to the differential concentration of Endo-PG and Exo-PMG in Fructozym and PGzyme preparations. Where they have higher amounts of Endo-PG and Exo-PMG, consequently they could convert insoluble pectin into soluble pectin leading to augment the clarity and decrease the turbidity of the juice (Byaruagaba-Bazirake et al., 2012; Kyamuhangire et al., 2002).

Consequently, banana fruits which are treated with Fructozym or PGzyme preparation produce higher clarity and lower turbidity juice than that treated with Flavourzyme (Fig. 4).

\section{Browning index (BI) and reducing sugar (RS) content of banana juice}

The $\mathrm{BI}$ is the first impression for the juice quality. Where the obscure juice would mean that the product was deteriorated (Abdullah et al., 2007). As shown in Fig. (5) $\mathrm{BI}$ of control sample is 1.915 units 
decreased to 0.186 and 0.267 units for Fructozym and PGzyme, respectively. The $\mathrm{BI}$ of juice extracted by Fructozym is 0.186 significantly $(p<0.05)$ lower than that of juice extracted by PGzyme (0.267). No markedly difference is recorded between control sample and juice extracted by Flavourzyme. At the same time, reducing sugar (RS) increases due to the enzyme treatment. The highest concentration of RS is $113.21 \mathrm{mg} / \mathrm{ml}$ detected in the juice extracted by Fructozym followed by PGzyme (44.07 mg/ml). The increment in the reducing sugar could be correlated with the exo-polysaccharidases especially Exo-PG (Lanzarini and Pifferi, 1989). The variations in the $R I$ and $R S$ could be related to the different concentrations of carbohydrate hydrolases such as cellulases, hemicellulases and pectinases in the commercial and PGzyme preparations.

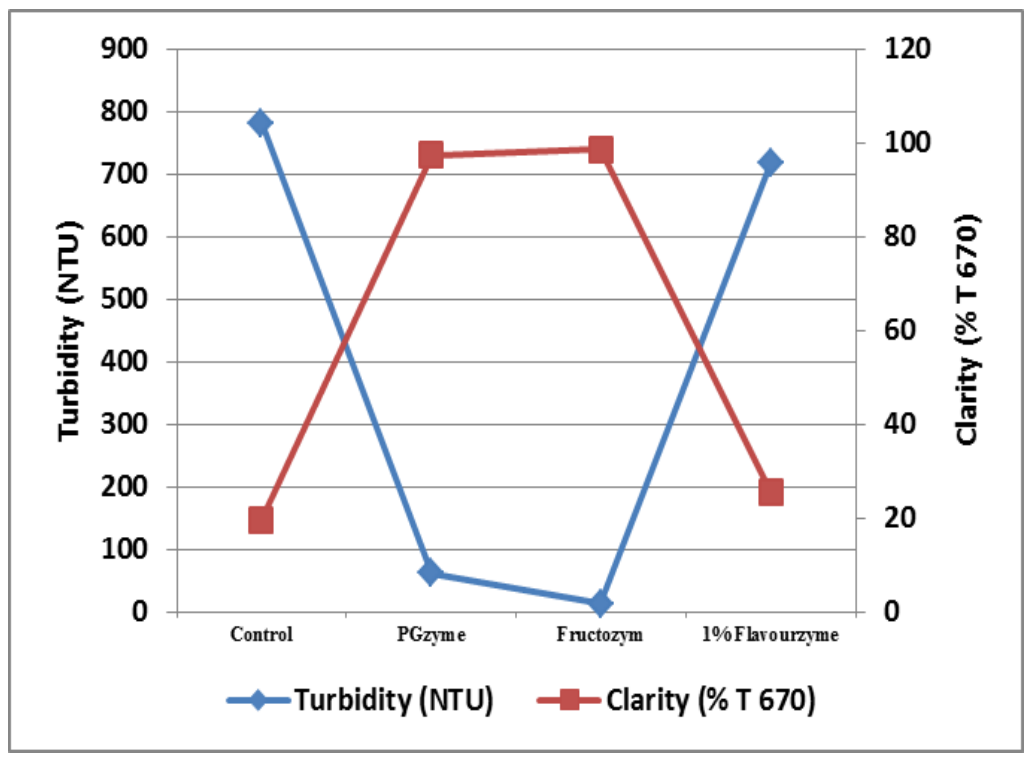

Figure (3): Turbidity and clarity of banana juice as affected by enzymes treatment

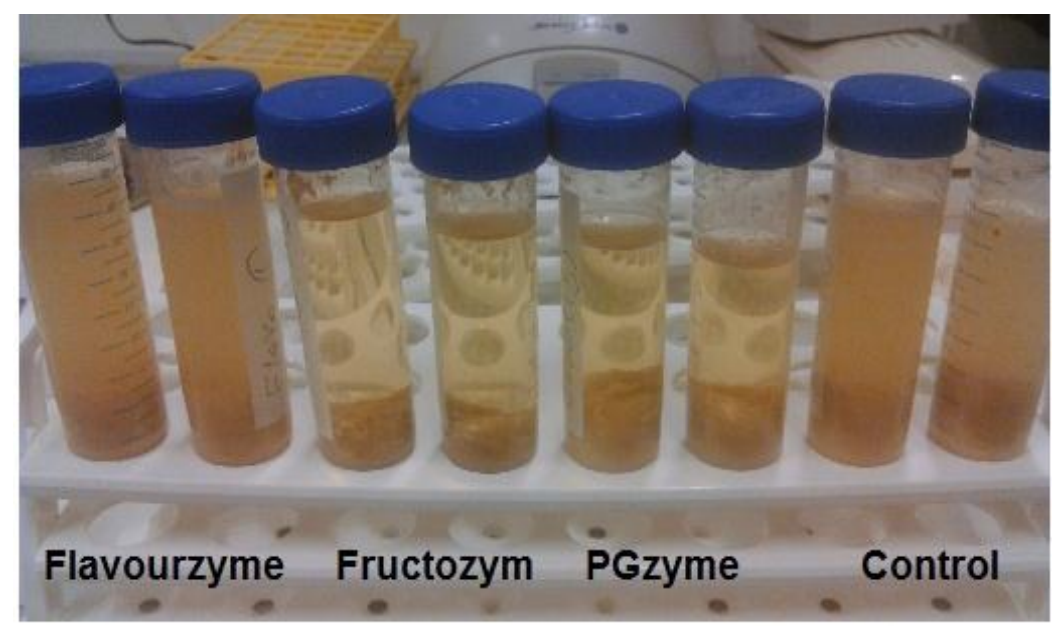

Figure (4): Clarity and turbidity of banana juice as affected with different enzymes treatment 


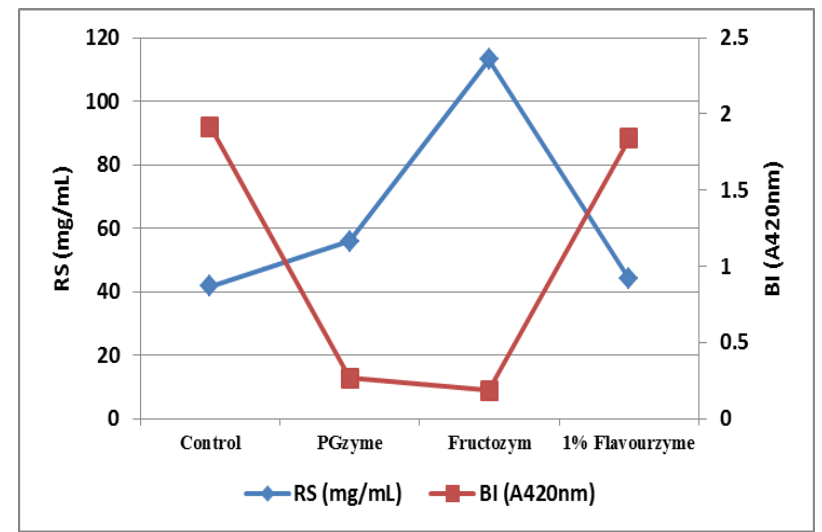

Figure (5): Browning index (BI) and reducing sugars content (RS) of banana juice as affected by enzymes treatment

These results are in full agreement with those reported in the literature before (Mabesa et al., 1989; Kyamuhangire et al., 2002; Fundira et al., 2002).

\section{Refractive index (RI) and total soluble solids (TSS)}

Reflective index (RI) of banana juice tends to slightly decline as a function of the enzyme treatment. On the other hand, TSS content increases. The significantly highest concentration of $\mathrm{TSS}$ is $\left(17.5^{\circ} \mathrm{Brix}\right)$ in the juice extracted by Fructozym followed by PGzyme (16.25 Brix) (Fig. 6). While, the lowest $\mathrm{RI}$ is (1.351) in banana juice extracted by PGzyme followed by that of Fructozym (1.353). This means the long chain of pectin and other polysaccharides falls short in length as a result of breakdown the glycosidic linkages in the backbone of pectin and other polysaccharides. Such results are obtained by ByaruagabaBazirake et al. (2012).

\section{The $\mathrm{pH}$ of banana juice}

The $\mathrm{pH}$ values of banana juice extracted by both Fructozym (4.43) and PGzyme (4.67) are significantly $(p>0.05)$ lower than those found in control (4.84) and juice extracted by Flavourzyme (4.82) (Table 2). But no significantly $(p>0.05)$ differences are found between pH's banana juices extracted by Fructozym (4.43) or PGzyme (4.67). This may be related to the activity of Exo-PG and Exo-PMG in the enzymes preparation (Fructozym and PGzyme) which split galacturonic acid and release in the juice leading to increase its acidity. As a results, the $\mathrm{pH}$ of the juice decreases.

Generally, the variations in the juice yield, viscosity, Browning index, Reducing sugars content, reflective index and total soluble solids of banana juice refractive index, total soluble solid could be related to the different concentrations of carbohydrate hydrolases such as cellulases, hemicellulases and pectinases in the commercial and PGzyme enzyme preparations. Expecting that the increment in the reducing sugar could be correlated with the exo-polysaccharidases especially Exo-PG (Lanzarini and Pifferi, 1989). These results are in the line of Tadakittisarn et al. (2007) and Byaruagaba-Bazirake et al. (2012). Therefore, the high TSS of juice extracted by enzyme preparation may be explained by the degradation of pectin, cellulose and hemicelluloses in the cell wall, causing release of some neutral sugars and leading to increment of -Brix degree. Dorreich (1993) reported that such BBrix increase can be as high as $10 \%$. In this respect Lanzarini and Pifferi (1989) pointed out the use of pectinase can considerably increase the soluble solids and reduce the viscosity of the fruit pulp. It is clear from the previous data that the quality of banana juice extracted with the aid of enzyme preparations (Fructozym and/or PGzyme) is improved. 


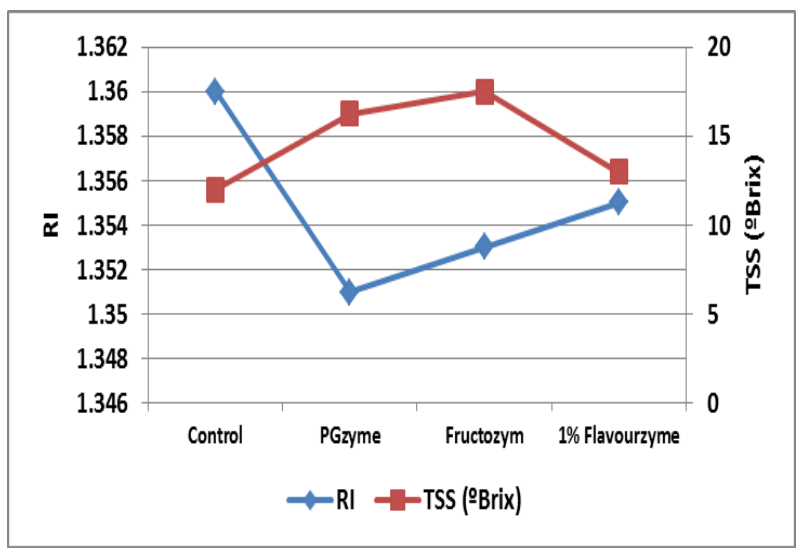

Figure (6): Refractive index (RI) and total soluble solid content (TSS) of banana juice as affected by enzymes treatment

Table 2: $\mathrm{pH}$ of banana juice as affected by enzymes treatment

\begin{tabular}{|l|c|c|c|c|}
\hline Characteristic & Control & PGzyme & Fructozym & $1 \%$ Flavourzyme \\
\hline $\mathrm{pH}$ & $4.84 \pm 0.01 \mathrm{a}$ & $4.67 \pm 0.01 \mathrm{~b}$ & $4.43 \pm 0.01 \mathrm{c}$ & $4.82 \pm 0.01 \mathrm{a}$ \\
\hline
\end{tabular}

$\mathrm{M} \pm \mathrm{SD}=$ means and standard deviation of three successful trails

In a row, means followed by the same letter are not significantly different at $5 \%$ level

In conclusion, utilization of PGzyme and lor Fructozym preparations could be an excellent and promising tool to extract and clarify banana juice from pulp fruits at commercial scale.

\section{REFERENCE}

Abdullah, A. G. L., N. M. Sulaiman, M. K. Aroua and M. J. M. M. Noor (2007). Responses Surface optimization of conditions for clarification of carambola fruit Juice using a commercial enzyme. Journal of Food Engineering. 81:65-71.

Al-Hooti, S. N., J. S. Sidhu, J. M. Al-Sager and A. Al-Othman (2002). Chemical composition and quality of date syrup as affected by pectinase/ cellulose enzyme treatment. Food Chemistry.79:215-220.

AOAC (1995). Association of Official Analytical Chemists."Official Methods of Analysis ". $13^{\text {th }}$ ed., Washington, DC, USA.
Bradford, M. M. (1976). A rapid and sensitive method for the quantitation of microgram quantities of protein utilizing the principle of protein-dye binding. Analytical .Biochemistry.72: 248-254.

Byaruagaba-Bazirake, G. W., P. Van Ransburg and W. Kyamuhangire (2012). Characteristics of enzyme-treated banana juice from three cultivars of tropical and subtropical Africa. African. Journal of Food Science and Technology. 3(10):277-290.

Dorreich, K. (1993). New Fruit Juice Technologies with Enzymes. Proceeding $23^{\text {rd }}$ Symposium of International Federation of Fruit Juice Producers, Budapest, Hungary,Pp 51-62.

Emerald, F. M. E. and V. V. Sreenarayanan (1999). Prolonging storage life of banana fruits by sub-atmospheric pressure. Indian Food Packer. 48:22-27.

Fundira, M., M. Blom, I. S. Pretorius and P. Van Rensburg (2002). Comparison of 
commercial enzymes for the processing of marula pulp, wine and spirits. Journal of Food Science. 67: 2346-2351.

Grassin, C. and P. Fauquembergue (1996). Fruit juices. In: Godfrey $\mathrm{T}$ and West $\mathrm{S}$ (eds.), Industrial Enzymology, $2^{\text {ed }}$. Stockholm Press, New York, pp. 225264.

Heerd, D., S. Yegin, C. Tari and M. Fernandez-Lahore (2012). Pectinase enzyme-complex production by Aspergillus spp. in solid-state fermentation: A comparative study. Food and Bioproducts. Processing. 90(2), 102110.

Heerd, D. (2013). Pectinolytic enzymes of Aspergillus sojae ATCC 20235: The impact of bioprocessing strategy on solidstate production and downstream processing of polygalacturonase. Doctor of Philosophy in Biochemical Engineering. School of Engineering and Sciences, Jacobs University Bremen

Hoondal, G. S., R. P. Tiwari, R. Tewari, N. Dahiya and Q. K. Beg (2002). Microbial alkaline pectinases and their industrial applications: a review. Applied of Microbiology and Biotechnology. 59: 409418.

Jayani, R. S., S. Saxena and R. Gupta (2005). Microbial pectinolytic enzymes: A review. Process Biochemistry.40: 29312944.

Johnson, J. R., R. J. Braddock and C. S. Chen (1995). Kinetics of ascorbic acid loss and nonenzymatic browning in orange juice serum: experimental rate constants. Journal of Food Science. 60(3): 502-505.

Kashyap, D. R., P. K. Vohra, S. Chopra and R. Tewari (2001). Application of pectinases in the commercial sector: Review. Bioresource. Technology. 77: 215-222.

Kulkarni, S. G., P. Vijayan and L. Shubha (2010). Effect of processing of dates into date juice concentrate and appraisal of its quality characteristics. Journal of Food Science and Technology. 47(2):157-161. Kyamuhangire, W., H. Myhre, H. T. Sorensen and R. Pehrson (2002). Yield, characteristics and composition of banana juice extracted by the enzymatic and mechanical methods. Journal of the Science and Food Agriculture. 82: 478482.

Lanzarini, G. and P. G. Pifferi (1989). Enzymes in fruit industry. In: Cantarelli $C$ and Lanzarini $G$ (Eds). Biotechnolog Application in Beverage Production, NewYork. Elsevier Applied Science. Pp. 189-221.

Lee, W. C., S. Yusof, N. S. A. Hamid and B. S. Baharin (2006). Optimizing conditions for enzymatic clarification of banana juice using response surface methodology (RSM).Journal of Food Engineering.73: 55-63.

Mabesa, B. L., R. A. A. De Lange and T. A. Tan (1989). Extraction of banana juiceusing commercial pectinase preparation. Philippine Journal of Crop Science. 14(1): 41-44.

Miller, G. L. (1959). Use of dinitrosalicylic acid reagent for determination of reducing sugar. Analytical Chemistry.31: 426-428.

Mohapatra, D., S. Mishra, C. B. Singh and D. S. Jayas (2011). Postharvest processing of banana: opportunities and challenges. Food Bioprocducts and Technology. 4(3): 327-339.

Moussa-Ayoub, T. E., S. K. El-Samahy, L. W. Kroh and S. Rohn (2011). Identification and quantification of flavonolaglycons in cactus pear (Opuntiaficusindica) fruit using a commercial pectinase and cellulose preparation. FoodChemistry.124 (3):1177-1184.

Mutlu, M., K. Sarioglu, N. Demir, M. T. Ercan and J. Acar (1999). The use of commercial pectinase in fruit juice industry. Part I: viscosimetric 
determination of enzyme activity. Journal of Food Engineering. 41: 147-150.

Naidu, G. S. N. and T. Panda (1998). Production of pectolytic enzymes: a review. Bioprocess Engineering. 19: 355361.

Negrulescu, A., V. Patrulea, M. Mincea Manuela, C. Ionascu, A. Vlad-Oros Beatrice and V. Ostafe (2012). Adapting the reducing sugars method with dinitrosalicylic acid to microtiter plates and microwave heating. Journal of Brazilian Chemistry Society. 23(12): 2176-2182.

Ortiz-Gastón, E., E. Guitart-María, A. Edgardo, H. M. Fernández-Lahore and B. Martin (2014). Microplate assay for endo-polygalacturonase activity determination based on ruthenium red method. Analytical Biochemistry.454:3335.

Pandey, A., C. R. Soccol and D. Mitchell (2000). New developments in solid state fermentation: I. Bioprocesses and products.

Process Biochemistry.35:1153-1169.

Sagu, S. T., E. J. Nso, S. Karmakar and D. E. Sirshendu (2014). Optimisation of low temperature extraction of banana juice using commercial pectinase.Food Chemistry.151:182-190.

SAS (2004). 9.1 (TS1M3) Copyright (c) 2002-2003 by SAS Institute Inc., Cary, NC, USA. Licensed to Icfai Business School, Site 0049647001.

Shahaden, S. and A. Abdullah (1995). Optimizing enzyme concentration, pH and temperature in banana juice extraction. Asean Food Journal. 10(3): 107-111.

Silva, C. M. M. S., I. Soares de Melo and P. Roberto de Oliveira (2005). "Legninolytic enzymes production by GanodermasPP". Enzyme Microbiology and Technology. 37:324-329.

Sin, H. N., S. Yusof, N. S. A. Hamid and R. A. Rahman (2006). Optimization of enzymatic clarification of sapodilla juice using response surface methodology. Journal of Food Engineering.73: 313319.

Tadakittisarn, S., V. Haruthaithanasan, P. Chompreeda and T. Suwonsichon (2007). Optimization of Pectinase Enzyme Liquefaction of Banana 'Gros Michel' for Banana Syrup Production. Kasetsart Journal of Natural Science.41: $740-750$.

Vijayanand, P., S. G. Kulkarni and G. V. Prathibha (2010). Effect of pectinase treatment and concentration of litchi juice on quality characteristics of litchi juice. Journal of Food Science and Technology. 47 (2), 235-239.

Vishal, B. V., A. S. Chauhan, M. N. Rekha and P. S. Negi (2015). Quality evaluation of enzyme liquefied papaya juice concentrate (PJC) stored at various temperatures. Journal of Food Nutritional Science. 3(3): 90-97.

Youn, K. S., J. H. Hong, D. H. Bae, S. J. Kim and S. D. Kim (2004). Effective clarifying process of reconstituted apple juice using membrane filtration with filter-aid pretreatment. Journalof Membrane. Science. 228:179-186. 


\title{
Aspergillus sojae استخدام إنزيمات البكتينيز الخام PGzyme الناتجة من فطر
} (ATCC 20235)

\author{
جهاد محمد الثناوى ، محمد بسيم عطا
}

قسم علوم وتكنولوجيا الاغذية -كلية الزراعة - جامعة طنطا

\section{الملخص العزبى}

تهدف الدراسة لأستخدم أنزيم PGzyme الخام المنتج من فطر وراثيا في استخلاص و نرويق عصير الموز من الثمار الناضجة للموز مقارنة بنوعين من الأنزيمات البكتينية التجارية و التي

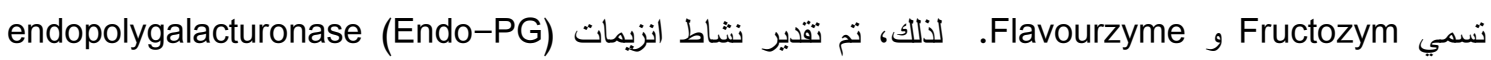
polymethylegalacturonase (PMG) و لكل مستحضر انزيمي. وقد بينت النتائج أن Fructozym هو أكثر فعالية في استنخلاص وترويق عصير الموز عن PGzyme في حين أن المستحضر الأنزيمي Flavourzyme كان لبس له تأثثر ملحوظ في استخلاص و نرويق عصبر الموز . كما تمت مناقثنة الخصائص الفيزيائية و الكيماوية لعصير الموز الناتج من أستخدام المستحضرات الأنزيمية المختلفة و التي شملتها الدراسة.

E-mail:mujareg@gmail.com
موقع المجلة

Mujareg.blogspot.com 
